\title{
REVERSE MERIDIONAL CYCLODIALYSIS AB INTERNO IN MANAGEMENT OF OPEN ANGLE GLAUCOMA — A PRELIMINARY REPORT
}

\author{
Kumar $\mathrm{V}^{1,2,3}$, Frolov MA ${ }^{1}$, Dushina $\mathrm{GN}^{1,3}$, Shradqa $\mathrm{AS}^{1,3}$, Bezzabotnov $\mathrm{Al}^{2,3}$, Abu Zaalan KA
}

1 Peoples' Friendship University of Russia, Moscow, Russia

2 Skhodnya City Hospital, Khimki, Moscow Region, Russia

${ }^{3}$ Centre for eye microsurgery "Pro zrenie", Khimki, Moscow Region, Russia

\begin{abstract}
The uveoscleral outflow as an alternate route of aqueous drainage is of great interest in glaucoma surgical treatment. A cyclodialysis cleft allows one to create a direct connection between the anterior chamber (AC) and the suprachoroidal space (SCS) which is the key element of uveoscleral outflow. The purpose of the study was to evaluate the safety and effectiveness of reverse meridional cyclodialysis ab interno (RMCai) in decreasing intraocular pressure (IOP) in patients with primary open-angle glaucoma (POAG) and refractory glaucoma (RG). Fourteen patients who exhibited POAG and RG (11 men and 3 women, age $77.3 \pm 7.8$ years) were included in the study. All patients underwent RMCai with the help of custom-designed spatula. The spatula, inserted through a clear corneal incision, was used to detach the ciliary body from the scleral spur to create a 2.0-2.5 mm wide and 6.0-6.5 mm deep cleft. Outcome measures were IOP change, use of hypotensive medication(s), complications, and need for a second surgery. Decrease in IOP by more than $20 \%$ and IOP between 6 and $21 \mathrm{mmHg}$ without hypotensive medication constituted complete success. Similar changes in IOP with medication constituted partial success. Need for second surgery constituted failure. The follow-up period was $>3$ months. Baseline IOP and hypotensive medication use were $22.0 \pm 8.5 \mathrm{mmHg}(95 \% \mathrm{confidence} \mathrm{interval} \mathrm{(Cl),}$ 17.6-26.4) and $2.6 \pm 0.9(95 \% \mathrm{Cl}, 2.2-3.1)$. At 3, 6, 12, 18, and 24 months, complete success was achieved in $64.3 \%, 77.8 \%, 55.6 \%, 37.5 \%$, and $40 \%$ of patients respectively; partial success - in 14.3\%, 22.2\%, 44.4\%, 50.0\%, and $60.0 \%$. Four patients required a second surgery. Failure occurred because of cleft closure by fibrosis. It was concluded that RMCai is safe and effective in decreasing IOP in POAG and RG patients.
\end{abstract}

Keywords: glaucoma, intraocular pressure, cyclodialysis, cyclodialysis ab interno, uveoscleral outflow

Author contribution: Kumar V — conception, design, data collection, analysis and interpretation, writing and editing, overall responsibility; Frolov MA — overall responsibility; Dushina GN — data collection and editing; Shradqa AS — conception, design and data collection; Bezzabotnov Al — conception, design and editing; Abu Zaalan KA — data collection.

Compliance with ethical standards: appropriate approval was obtained from the ethics committee of Peoples' Friendship University of Russia (protocol № 16 dated 17.11.2016), the study was conducted in accordance with the tenets of the World Medical Association Declaration of Helsinki. Informed consent was obtained from all patients after the experimental nature of the procedure had been fully explained.

Correspondence should be addressed: Vinod Kumar

ul. Miklukho-Maklaya, 6, Moscow, 117198; kumarvinod1955@gmail.com

Received: 27.11.2019 Accepted: 11.12.2019 Published online: 16.12.2019

DOI: $10.24075 /$ brsmu.2019.081

\section{ОБРАТНЫЙ МЕРИДИОНАЛЬНЫЙ ЦИКЛОДИАЛИЗ АВ INTЕRNО В ЛЕЧЕНИИ ОТКРЫТОУГОЛЬНОЙ ГЛАУКОМЫ — ПРЕДВАРИТЕЛЬНЫЕ РЕЗУЛЬТАТЫ}

В. Кумар ${ }^{1,2,3}$, М. А. Фролов ${ }^{1}$, Г. Н. Душина ${ }^{1,3}$, А. С. Шрадка ${ }^{1,3}$, А. И. Беззаботнов²,3 К. А. Абу Заалан ${ }^{1}$

1 Российский университет дружбы народов, Москва, Россия

${ }^{2}$ Сходненская городская больница, Химки, Московская область, Россия

${ }^{3}$ Центр микрохирургии глаза «Про зрение», Химки, Московская область, Россия

Увеосклеральный путь оттока внутриглазной жидкости (ВГЖ) представляет большой интерес в хирургическом лечении глаукомы. Суть операции циклодиализа заключается в создании прямого сообщения между передней камерой (ПК) глаза и супрахориоидальным пространством (СХП), главным звеном увеосклерального пути оттока ВГЖ. Целью нашего исследования было оценить безопасность и эффективность обратного меридионального циклодиализа ab interno (ОМЦаi) в снижении внутриглазного давления (ВГД) у пациентов с первичной открытоугольной глаукомой (ПОУГ и рефрактерной глаукомой (РГ). У 14 пациентов с ПОУГ (11 мужчин и 3 женщины в возрасте 77,3 \pm 7,8 лет) был проведен ОМЦаі с помощью специально разработанного шпателя. Шпателем создавали циклодиализную щель шириной 2,0-2,5 мм и глубиной 6,0-6,5 мм. Критериями оценки успеха операции были динамика ВГД, потребность в дополнительной гипотензивной терапии и повторном хирургическом вмешательстве, а также наличие осложнений. Успех считали полным, если ВГД снижалось более чем на 20\% и оставалось в переделах 6-21 мм рт. ст. без применения гипотензивных средств. Признанный успех связывали с потребностью в гипотензивной терапии. Лечение считали неудачным, если возникала необходимость в повторном хирургическом вмешательстве. Пациенты оставались под наблюдением не менее трех месяцев. Исходное ВГД и количество используемых гипотензивных препаратов

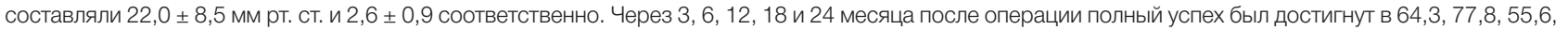
37,5 и 40\% случаев соответственно, признанный - в 14,3, 22,2, 44,4, 50 и 60\% случаев. Повторная операция потребовалась 4 пациентам. Причиной неудачи стала фиброзная облитерация циклодиализной щели. Было установлено, что ОМЦаі безопасен и эффективен в снижении ВГД у пациентов с ПОУГ и РГ.

Ключевые слова: глаукома, внутриглазное давление, циклодиализ, циклодиализ ab interno, увеосклеральный отток

Информация о вкладе авторов: В. Кумар - концепция и дизайн исследования, сбор и обработка материала, статистическая обработка, написание статьи, оформление графиков и рисунков, контроль выполнения исследования; М. А. Фролов - контроль выполнения исследования; Г. Н. Душина - сбор и обработка материала, редактирование статьи; А. С. Шрадка - концепция и дизайн исследования, сбор и обработка материала; А. И. Беззаботнов концепция и дизайн исследования, сбор и обработка материала, редактирование статьи; К. А. Абу Заалан - сбор и обработка материала.

Соблюдение этических стандартов: исследование одобрено этическим комитетом медицинского института Российского университета дружбы народов (протокол № 16 от 17 ноября 2016 г.), его проводили в соответствии с принципами Хельсинкской декларации Всемирной медицинской ассоциации. Все пациенты подписали добровольное информированное согласие на участие в исследовании.

$\bigotimes$ Для корреспонденции: Винод Кумар ул. Миклухо-Маклая, д. 6, г. Москва, 117198; kumarvinod1955@gmail.com

Статья получена: 27.11.2019 Статья принята к печати: 11.12.2019 Опубликована онлайн: 16.12.2019

DOI: $10.24075 /$ vrgmu.2019.081 
Open-angle glaucoma $(O A G)$ is the leading cause of irreversible blindness worldwide [1]. Although glaucoma is a multifactorial disease, its management primarily focuses on control of intraocular pressure (IOP). Notably, IOP can be controlled either medically or by laser treatment. For patients with glaucoma that is refractory to medical or laser treatment, surgical management is indicated.

In the past, surgical techniques focused on creation of an artificial pathway for aqueous humor to bypass obstacles in drainage from the anterior chamber (AC); this led to development of penetrating glaucoma surgeries. A classic form of these surgeries is trabeculectomy [2], which is regarded as the gold standard in surgical management of glaucoma; its hypotensive effect remains for an extended period, but many complications arise during surgery and in the postoperative period [3, 4]. Development of non-penetrating surgeries (deep sclerectomy and its various modifications) reduced the complication rate; however, these techniques provide only a short-term hypotensive effect [5].

Recently, minimally invasive glaucoma surgeries have been developed to enhance the natural trabecular outflow, which comprises the conventional route of aqueous drainage $[6,7]$. These surgeries are safe, and patient rehabilitation is rapid; notably, such surgeries do not involve use of a bleb, which enables them to remain free from bleb-related complications, such as cosmesis, bleb leakage, bleb infection, and endophthalmitis [6]. However, there are certain limitations which are associated with these surgeries. Their IOP-lowering effects are dependent upon episcleral vein pressure, and IOP decrease is moderate [8].

There also exists an alternate route of aqueous drainage: uveoscleral outflow. Because of its anatomical and physiological characteristics, uveoscleral outflow has tremendous potential for use in controlling IOP. This outflow, which comprises approximately half of the aqueous drainage in normal human eyes [9, 10], occurs by bulk flow of aqueous humor through the ciliary muscle into the suprachoroidal space (SCS); then flows into the choroid and suprachoroidal clefts, subsequently exiting the eye through perivascular spaces of the emissarial scleral channels, or directly through permeable scleral collagen bundles. There is a possible connection between the uveoscleral outflow pathway and the lymphatic system of the eye and orbit, which maintains tissue fluid balance [11]. A gradient of negative pressure within the SCS serves as the conduit for this aqueous flow pathway. Notably, exploitation of this pathway may enable development of safer and less invasive techniques with improved surgical success, which may thus increase quality of life for glaucoma patients.

A technique for reverse meridional cyclodialysis ab interno (RMCai) has been developed (patent of Russian Federation N 2676967, dated 19.01.2019) and a pilot study was undertaken to evaluate its safety and effectiveness in decreasing IOP in patients with POAG and RG [12].

The purpose of the study was to evaluate the safety and effectiveness of RMCai in decreasing IOP in patients with $P O A G$ and $R G$.

\section{METHODS}

In a consecutive interventional case series, a total of 17 patients ( 11 men and 6 women) who exhibited POAG and RG were operated upon during the period from February 2015 to December 2017. The average age of the patients was $77.3 \pm 7.8$ years $(95 \% \mathrm{Cl} 73.2-81.4)$. Inclusion criteria: $P O A G$ or RG, more than 3 months of follow-up. Glaucoma patients having visually significant cataract, thus requiring a combined procedure (phacoemulsification and hypotensive surgery), were also included. Exclusion criteria: angle-closure glaucoma, neovascular glaucoma, secondary glaucoma, or crystalline lens-induced glaucoma.

A complete ophthalmological examination was performed before surgery including visual acuity evaluation, IOP measurement (by Maklakov's method or with tonometer), slit lamp biomicroscopy, 78 diopter ophthalmoscopy, perimetry, and gonioscopy. For statistical purposes, IOP values obtained by Maklakov's method were converted to P0, using a custom conversion table [13]. For IOP measurement by ICare tonometer ic100 (Icare Finland Oy; Finland) the median of 3 consecutive measurements per eye was analyzed [14, 15].

\section{Surgical technique}

Only 1 eye per patient was eligible for surgery. Retrobulbar anesthesia was preferred. After insertion of the lid speculum, a clear corneal incision $(2.75 \mathrm{~mm})$ was made at the 10-11 o'clock position. The AC was irrigated with $0.2-0.3 \mathrm{ml}$ of $0.01 \%$ solution of carbachol (Appasamy Ocular Devices, Pvt. Ltd.; India) to constrict the pupil and pull the iris away from the angle. The AC was filled with cohesive viscoelastic device, the $1.4 \%$ solution of sodium hyaluronate (Beaver Visitec International, Inc.; USA). Two paracenteses were made at $180^{\circ}$ apart from each other. The patient's head was turned away from the surgeon by approximately $30^{\circ}$ and the optical head of the operating microscope was tilted by $30^{\circ}$ toward the surgeon. A surgical goniolens, held in the left hand of the surgeon, was placed on the cornea and angle structures were identified and studied. A custom-designed cyclodialysis spatula (Fig. 1) was inserted into the AC through the corneal incision, and the ciliary body was gently detached from the scleral spur.

Through this cleft the spatula was further meridionally advanced via slight sideways movements until a 6-6.5-mm long and $2.0-2.5-\mathrm{mm}$ wide tunnel was made in the SCS, thereby joining the AC with the SCS. The spatula and goniolens were withdrawn. The patient's head and the operating microscope were returned to their primary positions. If hemorrhage occurred from the cyclodialysis site, a "wait and watch" strategy was used. Typically, bleeding stopped spontaneously after some time. Viscoelastic device was irrigated out from the AC by using a bimanual technique with the aid of irrigating and aspirating cannulas inserted through the paracentesis. An air bubble was

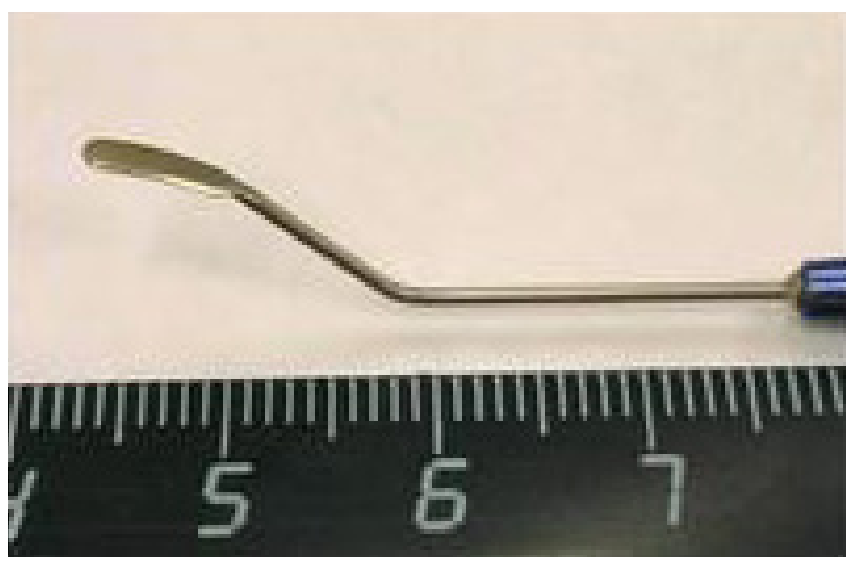

Fig. 1. Side view of the custom-designed spatula for reverse meridional cyclodialysis ab interno: distal end of the working portion of the spatula is $6.0-6.5 \mathrm{~mm}$ long and $2.0 \mathrm{~mm}$ wide; further, it is curved and repeats globe curvature 
injected into the $\mathrm{AC}$ in order to prevent cleft closure. At the end of the operation, all incisions were sealed by hydration of the corneal stroma. Then, $0.2-0.3 \mathrm{ml}$ of dexamethasone solution was injected subconjunctivally, and antibiotic ointment was placed in the conjunctival sac. A monocular patch was applied. In eyes with coexisting pathology, ultrasound phacoemulsification (phaco) was performed with initial implantation of a foldable hydrophilic intraocular lens (IOL). Before RMCai, all viscoelastic was removed from behind the IOL through irrigation. The pupil was constricted by irrigating the AC with carbachol solution and the AC was filled with cohesive viscoelastic. RMCai was performed as per the technique described above. Incisions were sealed by hydration of the corneal stroma.

\section{Follow-up evaluation}

Follow-up evaluation was performed as following. Patients discontinued IOP-lowering medications 1 day before surgery. Oral acetozolamide $0.25 \mathrm{~g}$ (Diacarb, Polpharma, Starogard Gdański; Poland) twice daily was prescribed for 1 day; patients were instructed to resume IOP-lowering medications only if the investigator determined that additional IOP lowering was needed. After surgery, patients were instructed to instill antibiotic and steroid eye drops for a period of 10-12 days. Patients were evaluated daily during hospital stay, after 1 week, and at 1, 3, 6, 12,18 , and 24 months after surgery. Postoperative assessment included visual acuity evaluation, tonometry, biomicroscopy, and ophthalmoscopy. If corneal condition allowed, eyes were evaluated via gonioscopy; wherever possible, findings were documented via photography and videography. Adverse events (if any) and number of glaucoma medications used were noted. Field of vision was tested with an interval of 6 months or 1 year.

\section{Outcome measures and statistical analysis}

The primary outcome was IOP change. The secondary outcomes were pre- and postoperatively used number of hypotensive medications, as well as complications and need for a second surgery. Reduction in IOP $>20 \%$ and IOP between 6 and $21 \mathrm{mmHg}$ without medication constituted complete success; similar changes in IOP with medication constituted partial success. Failure constituted IOP $<6 \mathrm{mmHg}$ or $>21 \mathrm{mmHg}$, IOP reduction $<20 \%$, or subsequent need for second glaucoma surgery. Success rates were evaluated at each follow-up visit, beginning 3 months after surgery.

Statistical analysis was performed using Microsoft Excel 2007 (Microsoft; USA) at each follow-up visit, considering changes in the number of patients. Paired Student's $t$-tests were used for IOP and medication analyses. Differences were significant when $p<0.05$.

\section{RESULTS}

Fourteen eyes of 14 patients ( 11 man and 3 women) fulfilled the inclusion criteria. The baseline characteristics of the patients are described in Table 1.

Right eyes underwent operation in 5 patients, while left eyes - in 9 patients. Severe glaucomatous damage was present in 11 eyes (79\%). Eight eyes (57\%) had previously undergone surgery for glaucoma; of these, 3 underwent a combined surgical procedure in the present study: phaco with implantation of an acrylic hydrophilic IOL along with glaucoma surgery.

The mean follow-up period was $68.2 \pm 44.2$ weeks $(95 \% \mathrm{C}$ 45.1-91.4). Two patients were lost to follow-up after 3 months; 1 patient was lost to follow-up after 18 months and 2 patients were lost to follow up after 24 months. Mean baseline IOP was $22.0 \pm 8.5 \mathrm{mmHg}(95 \% \mathrm{Cl} 17.6-26.4)$. A significant reduction in mean IOP and use of hypotensive medications was observed at each time point (Table 2). There were no cases of hypotony at any follow-up visits.

Success rate outcomes are described in Table 3.

Three eyes (21.4\%) underwent repeat glaucoma surgery after 3 months following RMCai; 1 eye underwent repeat glaucoma surgery after 18 months. The Kaplan-Meier survival curve is shown in Fig. 2.

The mean best-corrected visual acuity before surgery was $1 \pm 0.9$ logarithm of the minimum angle of resolution (LogMAR). Mean LogMAR at 3, 6, 12, 18 and 24 months was $0.9 \pm 0.9$, $1.0 \pm 1.0,0.9 \pm 1.0,0.8 \pm 1.0$, and $0.6 \pm 0.5$, respectively.

In 11 of 14 eyes (79\%), there was some hemorrhage at the cleft site, obscuring the view of the tunnel. In these eyes,

Table 1. Patient demographics

\begin{tabular}{|c|c|c|c|c|c|}
\hline № & Sex/age & Eye & Previous glaucoma surgeries & Other ocular surgeries & Concomitant pathology \\
\hline 1 & $F / 74$ & LE & $\begin{array}{l}\text { 1. MTF } \\
\text { 2. SDSC }\end{array}$ & - & Cataract \\
\hline 2 & M / 82 & RE & - & - & Cataract \\
\hline 3 & $F / 87$ & RE & - & - & Cataract \\
\hline 4 & $\mathrm{M} / 87$ & $\mathrm{RE}$ & - & - & Cataract \\
\hline 5 & $\mathrm{M} / 87$ & LE & 1. Trabeculectomy & - & Cataract \\
\hline 6 & $\mathrm{M} / 82$ & LE & - & - & Cataract \\
\hline 7 & M / 64 & RE & - & - & Cataract \\
\hline 8 & M / 69 & LE & 1. Trabeculectomy & - & Cataract \\
\hline 9 & M / 69 & LE & 1. Trabeculectomy & - & Cataract \\
\hline 10 & $\mathrm{M} / 78$ & RE & 1. Trabeculectomy & - & Cataract \\
\hline 11 & $\mathrm{M} / 77$ & LE & 1. Trabeculectomy & Phaco + IOL & Pseudophakia \\
\hline 12 & $\mathrm{M} / 75$ & LE & - & - & Cataract \\
\hline 13 & M / 64 & LE & 1. SDSC & Phaco + IOL & Pseudophakia \\
\hline 14 & $F / 82$ & LE & $\begin{array}{l}\text { 1. SDSC } \\
\text { 2. Trabeculectomy }\end{array}$ & Phaco + IOL & Pseudophakia \\
\hline
\end{tabular}

Note: M — male; F — female; RE — right eye; LE — left eye; MTF — Singh's microtrack filtration operation; SDSC — segmental dilation of Schlemm's canal (implantation of Kumar's stainless-steel spiral expander in lumen of Schlemm's canal); Phaco — phacoemulsification; IOL — intraocular lens. 
hemorrhage either stopped spontaneously after some time, or a bolus of viscoelastic was placed at the tunnel opening. In 3 eyes that underwent combined surgery, some blood reached the capsular bag behind the IOL. In these eyes, the blood was washed out with the aid of irrigating and aspirating cannulas.

In 11 of 14 eyes (79\%), the early rehabilitative period was uneventful. In 3 eyes on the first postoperative day, hyphema was observed, which resolved within 1 week without any specific treatment. No second visit to the operation theatre was required because of hyphema. Furthermore, there were no noticeable complications in the late postoperative period. During gonioscopic evaluation of the cyclodialysis site at 3 , $6,12,18$, and 24 months after surgery, the cleft was open in $10,8,8,5$, and 3 eyes, respectively; moreover, the cleft was noticeably shallow in 3, 4, 6, 4, and 2 eyes, respectively, and completely closed in 4, 2, 1, 3, and 3 eyes, respectively (Fig. 3).

In all eyes with unsuccessful outcome, retrograde placement of the iris root at the cyclodialysis site was prevalent. During ultrasonic biomicroscopy of the $\mathrm{AC}$ angle in eyes with successful outcome, the cyclodialysis cleft could be easily identified.

\section{DISCUSSION}

Glaucoma surgery in the SCS has several important advantages relative to penetrating procedures. Some surgeons have attempted to improve supraciliary outflow using a nonpenetrating deep sclerectomy procedure [16-18]. The results were encouraging, but not definitive. It is likely that the presence of a conjunctival bleb as a main filtration site for the aqueous humor did not completely open this pathway, thus affecting the final results.

The SCS offers the surgeon 2 surgical approaches: $a b$ externo and ab interno. In the ab externo approach, a direct passage is created from the AC to the SCS by separation of the ciliary body from the scleral spur. This approach is easy to learn and does not require mastery of unfamiliar techniques and maneuvers. However, it requires extensive dissection of ocular tissues, and is thus very traumatic to the eye. There is a high risk of complications, such as postoperative hypotony and massive bleeding from scleral vessels. Several studies have demonstrated that when the SCS is reached through an ab externo approach, fibroblast activation is a primary cause of surgical failure $[19,20]$.

There are certain advantages with ab interno approach. This approach spares conjunctival dissection, retaining this structure in an intact state, which may be useful for future glaucoma procedures. It is minimally invasive and less traumatic; the resulting reduction in scarring leads to increased success rate. This surgery can be performed as an ambulatory procedure. The numbers of intraoperative and postoperative complications are negligible, and they are easily managed. The ab interno procedure can be performed, regardless of whether previous traditional glaucoma surgeries (e.g., trabeculectomy) have depleted viable conjunctiva tissue. The rehabilitation period is short [21-23]. However, this approach also involves limitations: it requires the use of costly instruments and apparatuses, such as an operating microscope in which the optical head can be tilted, as well as a surgical goniolens and viscoelastic devices; moreover, the surgeon should be familiar with the intraoperative gonioscopy procedure.

The concept of creating direct communication between the AC and SCS for reduction of IOP is not new. The first operative procedure to employ incision through insertion of the ciliary body to enable communication between the chambers of the anterior segment and the suprachoroid was performed by Hancock in 1861 [24], who described 6 cases in which the operation was used.

In 1905, a procedure was described for operative detachment of the ciliary body from its insertion, using an operation that was described as cyclodialysis [20]. Notably, the success of the operation depended upon communication

Table 2. Efficacy data

\begin{tabular}{|c|c|c|c|c|c|c|}
\hline \multirow{3}{*}{$\mathrm{N}$ of patients at follow-up visit } & \multicolumn{6}{|c|}{ Follow-up visit } \\
\hline & Pre-operative & 3 months & 6 months & 12 months & 18 months & 24 months \\
\hline & 14 & 14 & 9 & 9 & 8 & 5 \\
\hline IOP change, $\mathrm{mmHg}$ & $22.0 \pm 8.5$ & $13.8 \pm 5.0$ & $11.9 \pm 3.4$ & $10.1 \pm 2.4$ & $12.9 \pm 3.9$ & $13.0 \pm 5.7$ \\
\hline (95\% Cl) & $(17.6-26.4)$ & $(11.2-16.4)$ & $(9.8-14.0)$ & $(8.6-11.7)$ & $(10.1-15.6)$ & $(8.4-17.6)$ \\
\hline$\%$ IOP decrease & - & $30.8 \pm 29.8$ & $36.0 \pm 35.1$ & $48.0 \pm 26.0$ & $35.5 \pm 35.6$ & $34.5 \pm 33.8$ \\
\hline$(95 \% \mathrm{Cl})$ & - & $(15.4-46.3)$ & $(14.3-57.7)$ & $(31.1-65.0)$ & $(10.8-60.2)$ & $(7.4-61.6)$ \\
\hline $\mathrm{N}$ of medications & $2.6 \pm 0.9$ & $0.5 \pm 0.8$ & $0.4 \pm 0.7$ & $0.6 \pm 0.7$ & $0.9 \pm 0.8$ & $1.0 \pm 0.9$ \\
\hline$(95 \% \mathrm{Cl})$ & $(2.2-3.1)$ & $(0.1-0.9)$ & $(0-0.8)$ & $(0.1-1.0)$ & $(0.3-1.5)$ & $(0.3-1.7)$ \\
\hline $\begin{array}{l}\mathrm{N} \text { of eyes requiring hypotensive medication } \\
\text { at baseline / } \mathrm{N} \text { of eyes at follow-up visit (\%) }\end{array}$ & $14 / 14(100)$ & 2/14 (14.3) & $2 / 9(22.2)$ & $4 / 9(44.4)$ & $4 / 8(50.0)$ & $3 / 5(60.0)$ \\
\hline $\mathrm{N}$ of patients requiring repeat surgery & 0 & 2 & 1 & 0 & 0 & 0 \\
\hline
\end{tabular}

Note: $\mathrm{N}$ - number; IOP — intraocular pressure; $\mathrm{Cl}$ - confidence interval.

Table 3. Success rate

\begin{tabular}{|c|c|c|c|c|c|}
\hline \multirow{3}{*}{$\mathrm{N}$ of patients at follow-up visit } & \multicolumn{5}{|c|}{ Follow-up visit } \\
\hline & 3 months & 6 months & 12 months & 18 months & 24 months \\
\hline & 14 & 9 & 9 & 8 & 5 \\
\hline $\mathrm{N}$ of patients lost to follow-up & 0 & 2 & 0 & 1 & 2 \\
\hline $\mathrm{N}$ of eyes with complete success (\%) & $9(64.3)$ & $7(77.8)$ & $5(55.6)$ & $3(37.5)$ & $2(40)$ \\
\hline $\mathrm{N}$ of eyes with partial success (\%) & $2(14.3)$ & $2(22.2)$ & $4(44.4)$ & $4(50)$ & $3(60)$ \\
\hline $\mathrm{N}$ of eyes with failure (\%) & $3(21.4)$ & 0 & 0 & $1(12.5)$ & 0 \\
\hline
\end{tabular}




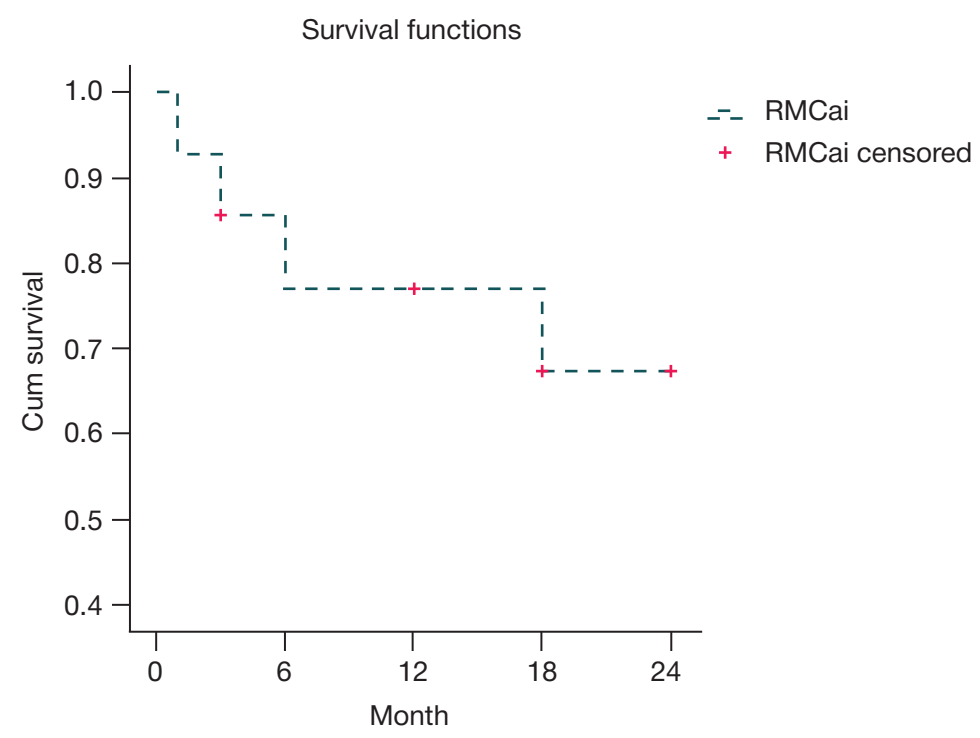

Fig. 2. Kaplan-Meier survival curve of eyes after RMCai
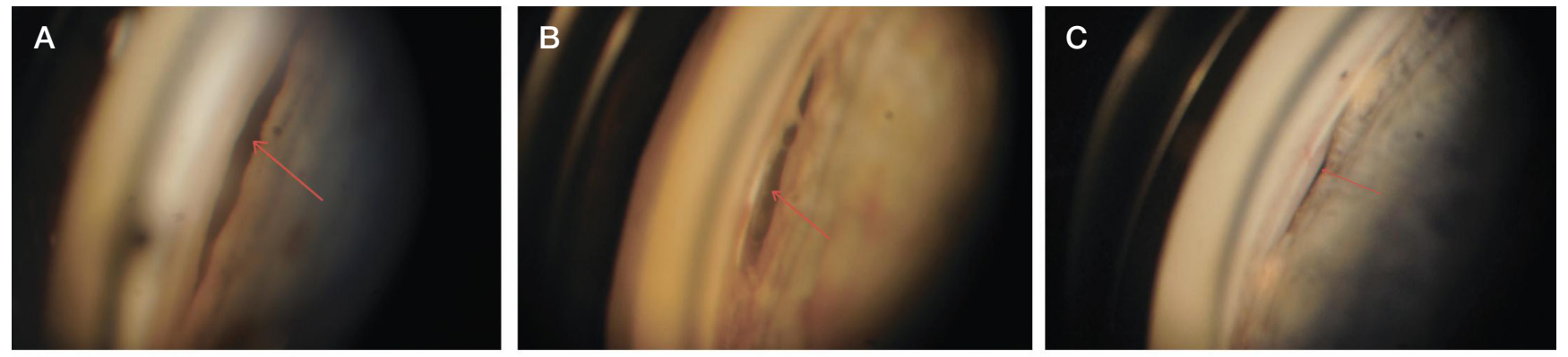

Fig. 3. Cyclodialysis cleft (red arrow) at different follow-up visits (different patients): 1 week (A); 1 month (B); 2 years (C); there are no signs of fibrosis or inflammation

between the AC and SCS. This hypothesis was supported by a number of works [25]. The other author [26] hypothesized that the operation acted by reducing pathologic accumulation of intraocular fluid by eliciting atrophy of the uveal tract.

The long-term success of this operation for reduction of IOP depends upon the patency of the cyclodialysis cleft. Notably, fibrosis of the cyclodialysis cleft may be the major factor for procedural failure; this has been reported by several authors [27-29]. Detailed morphological studies have demonstrated that fibroblasts and myofibroblasts are present throughout all layers of the choroid. These cells readily respond to trauma, surgical manipulation, and any foreign body by causing scar formation [30].

In our study, during gonioscopic evaluation of the cyclodialysis site, we noticed that in all eyes that showed procedural failure, there was reattachment of the iris root to the scleral wall. In most of these eyes, the reattachment site was posterior to its original anatomical attachment, constituting retrograde placement of the iris root. Our findings are like those reported by [27], who examined the angle of the $A C$ in 14 eyes that underwent cyclodialysis. All eyes that underwent successful operation showed surgical cyclodialysis or detachment of the iris root, combined with communication between the AC and SCS. Three unsuccessful operations resulted in reattachment of the iris root to the scleral wall; the site of reattachment in these cases was posterior to its original anatomical attachment, constituting retrograde placement of the iris root (as noted in our study).

In a prospective, consecutive, case-control study, a group of authors [31] included 28 eyes of 20 patients with intractable glaucoma. Under gonioscopic control, cyclodialysis ab interno was performed over 2 clock hours to enable access to the SCS. After surgery, baseline IOP decreased from $34.3 \pm 10.5$ to $14.6 \pm 12.4 \mathrm{mmHg}$. After a mean of 60 days, 21 eyes $(75 \%)$ required further surgical intervention. Qualified success was observed in 4 eyes (14.3\%); only 3 eyes (10.7\%) demonstrated complete success. In their series, the authors obtained the best results for phakic eyes. In our study, at 12, 18, and 24 months of follow-up, absolute success was achieved in 55.6\%, 37.5\%, and $40 \%$ of eyes, whereas partial success was achieved in $44.4 \%, 50.0 \%$, and $60.0 \%$ of eyes, respectively. Our results were more favorable than those of the prior study; this may be because minimum trauma occurred during surgery, due to the use of modern surgical microscopes and surgical goniolenses, which allowed identification of the anatomical structure of the angle.

There were several limitations to this study. These included absence of a control group, nonrandomized nature of the study, and small sample size $(n=14)$; further studies will require a larger sample of patients to confirm the findings reported here.

\section{CONCLUSION}

RMCai is an easy and safe procedure to perform, it effectively decreases IOP in patients with POAG and RG. Its success depends upon the patency of communication between the $\mathrm{AC}$ and SCS. Fibrosis of the cyclodialysis cleft is the primary reason for failure of this procedure. Use of measures to prevent its obliteration (e.g., implantation of various devices or materials to connect the AC with the SCS) may increase its success rate. 
1. Quigley HA, Broman AT. The number of people with glaucoma worldwide in 2010 and 2020. Br J Ophthalmol. 2006; (90): 262-7. PubMed PMID: 16488940.

2. Cairns JE. Trabeculectomy. Preliminary report of a new method. Am J Ophthalmol. 1968; (66): 673-9. PubMed PMID: 4891876.

3. Jampel HD, Musch DC, Gillespie BW, Lichter PR, Wright MM, Guire KE, et al. Perioperative complications of trabeculectomy in the collaborative initial glaucoma treatment study (CIGTS). Am J Ophthalmol. 2005; (140): 16-22. PubMed PMID: 15939389.

4. Francis BA, Hong B, Winarko J, Kawii S, Dustin L, Chopra V. Vision loss and recovery after trabeculectomy: risk and associated risk factors. Arch Ophthalmol. 2011; (129): 1011-17. PubMed PMID: 21825185.

5. El Sayyad F, Helal M, El-Kholify H, Khalil M, El-Maghraby A. Nonpenetrating deep sclerectomy versus trabeculectomy in bilateral primary open-angle glaucoma. Ophthalmology. 2000; (107): 1671-4. PubMed PMID: 10964827.

6. Saheb H, Ahmed II. Micro-invasive glaucoma surgery: current perspectives and future directions. Curr Opin Ophthalmol. 2012; (23): 96-104. PubMed PMID: 22249233.

7. Kahook MY, Sarwat S, Seibold LK. MIGS: advances in glaucoma surgery. Thorofare: SLACK Incorporated, 2014; 122 p.

8. Francis BA, Sarkisian SR, Tan JC. Minimally Invasive Glaucoma Surgery: A practical guide. New York: Thieme Medical Publisher, Inc., 2017; 199 p.

9. Alm A, Nilsson SF. Uveoscleral outflow - a review. Exp Eye Res. 2009; (88): 760-8. PubMed PMID: 19150349

10. Toris CB, Yablonski ME, Wang YL, Camras CB. Aqueous humor dynamics in the aging human eye. Am J Ophthalmol. 1999; (127): 407-12. PubMed PMID: 10218693

11. Yucel Y, Gupta N. Lymphatic drainage from the eye: A new target for therapy. Prog Brain Res. 2015; (220): 185-98. PubMed PMID: 26497791.

12. Kumar V, Frolov MA, Dushina GN, Shradka AS, Bezzabotnov Al. Obratnyi meridional'nyi tsiklodializ ab interno v khirurgicheskom lechenii glaukomy razlichnoi etiologii: otdalennye rezul'taty. Natsional'nyi zhurnal glaukoma. 2018; 17 (4): 63-73. Russian.

13. Krasnov MM. Mikrokhirurgiya glaukom. 2-e izdanie. Moscow: Meditsina, 1980; 248 c. Russian.

14. Kato Y, Nakakura S, Matsuo N, Yoshitomi K, Handa M, Tabuchi H, et al. Agreement among Goldmann applanation tonometer, iCare, and Icare PRO rebound tonometers; non-contact tonometer; and Tonopen XL in healthy elderly subjects. Int Ophthalmol. 2018; (38): 687-96. PubMed PMID: 28393323

15. Wong B, Parikh D, Rosen L, Gorski M, Angelilli A, Shih C. Comparison of disposable Goldmann applanation tonometer, iCare ic100, and Tonopen XL to standards of care Goldmann nondisposable applanation tonometer for measuring intraocular pressure. J Glaucoma. 2018; (27): 1119-24. PubMed PMID: 30134367.

\section{Литература}

1. Quigley HA, Broman AT. The number of people with glaucoma worldwide in 2010 and 2020. Br J Ophthalmol. 2006; (90): 262-7. PubMed PMID: 16488940.

2. Cairns JE. Trabeculectomy. Preliminary report of a new method. Am J Ophthalmol. 1968; (66): 673-9. PubMed PMID: 4891876.

3. Jampel HD, Musch DC, Gillespie BW, Lichter PR, Wright MM, Guire KE, et al. Perioperative complications of trabeculectomy in the collaborative initial glaucoma treatment study (CIGTS). Am J Ophthalmol. 2005; (140): 16-22. PubMed PMID: 15939389.

4. Francis BA, Hong B, Winarko J, Kawii S, Dustin L, Chopra V. Vision loss and recovery after trabeculectomy: risk and associated risk factors. Arch Ophthalmol. 2011; (129): 1011-17. PubMed PMID: 21825185.

5. El Sayyad F, Helal M, El-Kholify H, Khalil M, El-Maghraby A. Nonpenetrating deep sclerectomy versus trabeculectomy in bilateral primary open-angle glaucoma. Ophthalmology. 2000;
16. Chihara E, Hayashi K. Effect of a fenestration between an intrascleral lake and supraciliary space on deep sclerectomy. J Glaucoma. 2016 Apr; 25 (4): 299-307. DOI: 10.1097/ IJG.0000000000000277

17. Frolov MA, Frolov AM, Kazakova KA. Kombinirovannye metody lecheniya pri sochetanii katarakty i glaukomy. Vestnik oftal'mologii. 2017: 133 (4): 42-46. PubMed PMID: 28980565. Russian.

18. Lapochkin VI, Svirin AV, Korchuganova EA. Novaya operatsiya $v$ lechenii refrakternykh glaukom - limbosklerektomiya s klapannym drenirovaniem supratsiliarnogo prostranstva. Vestnik oftal'mologii. 2001; (1): 9-11. Russian.

19. Tanito M, Chihara E. Safety and effectiveness of gold glaucoma micro shunt for reducing intraocular pressure in Japanese patients with open angle glaucoma. Jpn J Ophthalmol. 2017; 61 (5): 388-94. PubMed PMID: 28600745.

20. Rekas M, Pawlik B, Grala B et al. Clinical and morphological evaluation of gold micro shunt after unsuccessful surgical treatment of patients with primary open-angle glaucoma. Eye (Lond). 2013; (27): 1214-17. PubMed PMID: 2387717.

21. Heine L. Introduction of cyclodialysis in glaucoma. Dtsch Med Wochenschr. 1905; (31): 824-26.

22. Kammer JA, Mundy KM. Suprachoroidal devices in glaucoma surgery. Middle East Afr J Ophthalmol. 2015; (22): 45-52. PubMed PMID: 25624673.

23. Bailey AK, Sarkisian SR, Jr, Vold SD. Ab interno approach to the suprachoroidal space. J Cataract Refract Surg. 2014; (40): 1291-4 PubMed PMID: 25088626.

24. Hancock H. Division of the ciliary muscle for glaucoma. Lancet. 1861: (77): 137.

25. Galin MA, Baras I, Sambursky J. Glaucoma and cataract. A study of cyclodialysis-lens extraction. Am J Ophthalmol. 1969; (69): 522-6. PubMed PMID: 5778611.

26. Krauss W. Ueber die Zyklodialyse. Zeitschr. f. Augenh. 1907; (17): 318.

27. Barkan O. Cyclodialysis: its mode of action. Histologic observations in a case of glaucoma in which both eyes were successfully treated by cyclodialysis. Arch Ophthal. 1950; (43): 793-803.

28. Kolesnikova LN, Pantsyreva LP, Svirin AV. Dilyatatsiya suprakhorioidal'nogo prostranstva $v$ kombinatsii $\mathrm{S}$ tsiklodializom. Vestnik oftal'mologii. 1976; (4): 18-20. PubMed PMID: 1021925. Russian.

29. Demeler U. Direct cyclopexy following operative and traumatic cyclodialysis. Fortschr Ophthalmol. 1984; (81): 466-8. PubMed PMID: 6500429.

30. Flügel-Koch C, May CA, Lütjen-Drecoll E. Presence of contractile cell network in the human choroid. Ophthalmologica. 1996; (210): 296-302. PubMed PMID: 8878213.

31. Jordan JF, Dietlein TS, Dinslage S, Lüke C, Konen W, Krieglstein GK. Cyclodialysis ab interno as a surgical approach to intractable glaucoma. Graefes Arch Clin Exp Ophthalmol. 2007; (245): 1071-6. PubMed PMID: 17219126.

(107): 1671-4. PubMed PMID: 10964827

6. Saheb H, Ahmed II. Micro-invasive glaucoma surgery: current perspectives and future directions. Curr Opin Ophthalmol. 2012; (23): 96-104. PubMed PMID: 22249233

7. Kahook MY, Sarwat S, Seibold LK. MIGS: advances in glaucoma surgery. Thorofare: SLACK Incorporated, 2014; 122 p.

8. Francis BA, Sarkisian SR, Tan JC. Minimally Invasive Glaucoma Surgery: A practical guide. New York: Thieme Medical Publisher, Inc., 2017; 199 p.

9. Alm A, Nilsson SF. Uveoscleral outflow — a review. Exp Eye Res. 2009; (88): 760-8. PubMed PMID: 19150349.

10. Toris $\mathrm{CB}$, Yablonski ME, Wang YL, Camras CB. Aqueous humor dynamics in the aging human eye. Am J Ophthalmol. 1999; (127): 407-12. PubMed PMID: 10218693.

11. Yucel Y, Gupta N. Lymphatic drainage from the eye: A new target for therapy. Prog Brain Res. 2015; (220): 185-98. PubMed PMID: 
26497791.

12. Кумар В., Фролов М. А., Душина Г. Н., Шрадка А. С., Беззаботнов А. И. Обратный меридиональный циклодиализ ab interno в хирургическом лечении глаукомы различной этиологии: отдаленные результаты. Национальный журнал глаукома. 2018; 17 (4): 63-73.

13. Краснов М. М. Микрохирургия глауком. 2-е издание. М.: Медицина, 1980; 248 с.

14. Kato Y, Nakakura S, Matsuo N, Yoshitomi K, Handa M, Tabuchi H, et al. Agreement among Goldmann applanation tonometer, iCare, and Icare PRO rebound tonometers; non-contact tonometer; and Tonopen XL in healthy elderly subjects. Int Ophthalmol. 2018; (38): 687-96. PubMed PMID: 28393323

15. Wong B, Parikh D, Rosen L, Gorski M, Angelilli A, Shih C. Comparison of disposable Goldmann applanation tonometer, iCare ic100, and Tonopen XL to standards of care Goldmann nondisposable applanation tonometer for measuring intraocular pressure. J Glaucoma. 2018; (27): 1119-24. PubMed PMID: 30134367.

16. Chihara E, Hayashi K. Effect of a fenestration between an intrascleral lake and supraciliary space on deep sclerectomy. J Glaucoma. 2016 Apr; 25 4): 299-307. DOI: 10.1097/ IJG.0000000000000277.

17. Фролов М. А., Фролов А. М., Казакова К. А. Комбинированные методы лечения при сочетании катаракты и глаукомы. Вестник офтальмологии. 2017; 133 (4): 42-6. PubMed PMID: 28980565.

18. Лапочкин В. И., Свирин А. В., Корчуганова Е. А. Новая операция в лечении ресрактерных глауком - лимбосклерэктомия с клапанным дренированием супрацилиарного пространства. Вестник офтальмологии. 2001; (1): 9-11.

19. Tanito M, Chihara E. Safety and effectiveness of gold glaucoma micro shunt for reducing intraocular pressure in Japanese patients with open angle glaucoma. Jpn J Ophthalmol. 2017; 61 (5): 388-94. PubMed PMID: 28600745.
20. Rekas M, Pawlik B, Grala B et al. Clinical and morphological evaluation of gold micro shunt after unsuccessful surgical treatment of patients with primary open-angle glaucoma. Eye (Lond). 2013; (27): 1214-17. PubMed PMID: 2387717.

21. Heine L. Introduction of cyclodialysis in glaucoma. Dtsch Med Wochenschr. 1905; (31): 824-26.

22. Kammer JA, Mundy KM. Suprachoroidal devices in glaucoma surgery. Middle East Afr J Ophthalmol. 2015; (22): 45-52. PubMed PMID: 25624673.

23. Bailey AK, Sarkisian SR, Jr, Vold SD. Ab interno approach to the suprachoroidal space. J Cataract Refract Surg. 2014; (40): 1291-4. PubMed PMID: 25088626.

24. Hancock $\mathrm{H}$. Division of the ciliary muscle for glaucoma. Lancet. 1861; (77): 137.

25. Galin MA, Baras I, Sambursky J. Glaucoma and cataract. A study of cyclodialysis-lens extraction. Am J Ophthalmol. 1969; (69): 522-6. PubMed PMID: 5778611.

26. Krauss W. Ueber die Zyklodialyse. Zeitschr. f. Augenh. 1907; (17): 318.

27. Barkan O. Cyclodialysis: its mode of action. Histologic observations in a case of glaucoma in which both eyes were successfully treated by cyclodialysis. Arch Ophthal. 1950; (43): 793-803.

28. Колесникова Л. Н., Панцырева Л. П., Свирин А. В. Дилятация супрахориоидального пространства в комбинации с циклодиализом. Вестник офтальмологии. 1976; (4): 18-20. PubMed PMID: 1021925

29. Demeler U. Direct cyclopexy following operative and traumatic cyclodialysis. Fortschr Ophthalmol. 1984; (81): 466-8. PubMed PMID: 6500429.

30. Flügel-Koch C, May CA, Lütjen-Drecoll E. Presence of contractile cell network in the human choroid. Ophthalmologica. 1996; (210): 296-302. PubMed PMID: 8878213.

31. Jordan JF, Dietlein TS, Dinslage S, Lüke C, Konen W, Krieglstein GK. Cyclodialysis ab interno as a surgical approach to intractable glaucoma. Graefes Arch Clin Exp Ophthalmol. 2007; (245): 1071-6. PubMed PMID: 17219126. 